\title{
ON EMAI VBI PHRASES ${ }^{*}$
}

\author{
Ronald P. Schaefer \& Francis O. Egbokhare \\ SIU Edwardsville \& University of Ibadan
}

\begin{abstract}
We examine the distribution of Emai prepositional phrases and their NP complements relative to intransitive verbs. In canonical order constructions, $v b i$ phrases follow a matrix verb as optional or obligatory constituents, or they follow the verb $z a$ in series before another matrix verb. In non-canonical order constructions, focused NP complements give rise to the verb $z a$ in series with only a subclass of intransitive verbs. Through lexical entry formats, we relate these distributional facts to distinct semantic roles and specific grammatical relations. Some vbi phrases show a complement relation for source and goal, but remaining phrases reflect inner locative complements or outer locative adjuncts, the latter signaled in focus constructions by $z a$. We also comment on $v b i$ prohibition outside the verb phrase and on its relationship to construal of affected object.
\end{abstract}

\section{Introduction.}

Recent study of West African languages has profiled the diachronic character of an oblique syntactic relation associated with a locative meaning. These locative markers have attracted attention primarily as end-state of a diachronic process whose initial-state was the category verb. Lord (1993), for instance, argues that

\footnotetext{
* Data incorporated in this paper derive from research support from the National Science Foundation (BNS \#9011338 and SBR \#9409552). Its preparation derives from support provided by the College and University Affiliates Program of the U.S. Department of State to Southern Illinois University Edwardsville and the University of Ibadan, Nigeria (ASJY 1333). We thank these institutions for their generous support, while not extending to them any responsibility for data interpretation. An earlier version of this paper was presented at the $35^{\text {th }}$ Annual Conference on African Linguistics at Harvard University. We thank audience members as well as the editor and reviewers of SAL for their helpful comments on earlier versions.
} 
Yoruba's contemporary preposition ní (1a) derives historically from a verb with locative significance, surviving today as a verb of possession with the sense 'have' (1b).
'He worked at home.'
$\begin{array}{lll}\text { b. ó ń́ } & \text { owó. } \\ \text { he have money }\end{array}$
'He has money.'

a. ó se isé ní ilè.

he do work at house

Nonetheless, little synchronic investigation in West Africa has assessed the distributional character of locative-marked constituents across fundamental construction types. Putting aside a diachronic perspective, we explore the synchronic behavior of prepositional phrases with locative significance in Nigeria's Edoid language Emai (Elugbe 1989, Williamson \& Blench 2000). It is a relatively strict SVO language showing an oblique syntactic relation that has locative significance. As data, we engage material from on-going documentation involving oral narrative texts (Schaefer \& Egbokhare 1999) as well as dictionary (Schaefer \& Egbokhare in press) and grammar descriptions.

Emai's locative prepositional phrases and their NP complements show a complex grammatical character. Phrases marked by the preposition vbi exhibit non-uniform distribution with intransitive verbs. ${ }^{1}$ They follow a matrix verb, or they follow the verb $z a$ in series before a matrix verb. In these positions $v b i$ phrases are either optional or obligatory. Vbi's NP complement also displays asymmetrical behavior. In focus position, it co-occurs with an added verb $z a$ in series with only a restricted set of intransitive verbs. To describe these distributional facts, we advance abbreviated verb entries that pair distinct semantic roles with complement or adjunct grammatical relations.

\section{Analysis of $v b i$ Phrases.}

$V b i$ serves as head of a prepositional phrase with locative character and governs a following NP constituent. It occurs with intransitive verbs but not in a symmetri-

${ }^{1}$ Attention is given only to intransitive verbs for reasons of practicality. Transitive verbs show quite similar behavior with respect to $v b i$, its NP complement and the occurrence of $z a$. 
cal fashion. This becomes evident when constructions with canonical order $S V$ $v b i N P$ are compared to those with non-canonical order where the NP complement of $v b i$ or its information question counterpart occupies focus position. The latter we take to be the leftmost slot in cleft (NP li $S$ 'it is NP that S') and information question constructions (i.e. ébé' $S$ 'where S') (cf. Watters 2000). Through comparison of canonical order and focus constructions, four covert intransitive verb categories can be discerned; they differ as to the obligatory or optional status of the $v b i$ phrase in canonical order structures and the occurrence of the verb $z a$ in cleft and information questions.

Category one intransitive verbs consist of activity verbs such as la 'run' and gbe 'dance'. Each of these verbs appears in constructions as a bare intransitive (2).
$\begin{array}{lllll}\text { a. ól1 } & \underline{o} v b e ̀ k h a ̀ n & \underline{o} & \underline{o} & \text { lá. }^{2} \\ \text { the } & \text { youth } & \text { SC } & \text { C } & \text { run }\end{array}$
'The youth is running.'

$\begin{array}{lllll}\text { b. óli ìkpòsò } & \underline{o} & \underline{o} & \text { gbé. } \\ \text { the } & \text { woman } & \text { SC } & \text { C } & \text { dance }\end{array}$

'The woman is dancing.'

Additionally, each can be followed by $v b i$ and its NP complement. In canonical order intransitive constructions for category one verbs, $v b i$-marked phrases appear in post-verbal position (vbí égbóa 'in the backyard' (3a), vbí ókhúnmí ùhài 'on top of the well' (3b)).

${ }^{2}$ Orthographic conventions for Emai are consistent with those in Schaefer (1987), Schaefer \& Egbokhare (1999), where $\underline{o}$ represents a lax mid back vowel, $\underline{e}$ a lax mid front vowel, and $v b$ a voiced bilabial approximant. Acute accent marks high tone, grave accent signals low, and acute accent followed by an apostrophe designates high downstep. Tone marking is for the most part grammatically conditioned by inflectional factors such as mood, aspect, polarity as well as syntactic position. This leads to variable tone marking on individual lexical items throughout a clause. We use the following abbreviations throughout this paper: $\mathrm{APP}=$ applicative, $\mathrm{ASS}=$ associative, $\mathrm{C}=$ continuous, $\mathrm{CS}=$ change of state, $\mathrm{F}=$ factative, $\mathrm{H}=$ Habitual, $\mathrm{IND}=$ indicative, $\mathrm{LOC}=$ locative, $\mathrm{PF}=$ positive focus, $\mathrm{R}=$ relator, $\mathrm{SC}=$ subject concord. 
(3)
a. ól óvbèkhàn ò $\underline{o}$ là vbí égbóà. the youth SC $\mathrm{C}$ run LOC backyard 'The youth is running in the backyard.'

b. óli òkpòsò ò ó gbè vbí ókhúnmí ùhài. the woman SC C dance LOC top well 'The woman is dancing on top of the well.'

The NP complement of a $v b i$ phrase in a canonical order construction may correspond to a focus constituent. Focus position immediately precedes $l i$ in clefts or occupies the ébé' 'where' slot in information questions. In both cleft and question constructions with category one verbs, the verb $z a$ 'be located' is obligatory (4a-b), with $v b i$ itself being disallowed in focus position as well as after the verbs la or $z a(4 \mathrm{c})$. Non-canonical order cleft and question constructions with category one verbs thus exhibit the verb $z a$, which is not overtly present in canonical order constructions.
a. égbóà li óli óvbékhán ó ò zá là. backyard PF the youth $\mathrm{SC} \mathrm{H}$ be.located run 'It is in the backyard that the youth runs.'
b. ébé' ólı óvbékhán ó ò zá là? where the youth $\mathrm{SC} \mathrm{H}$ bellocated run 'Where does the youth run?'
c. (*vbi) égbóà li ól1 óvbékhán ó $\underline{\text { ò }}$ zá $\quad$ (*vbi) là (*vbi). LOC backyard PF the youth $\mathrm{SC} \mathrm{H}$ belocated LOC run LOC 'It is in the backyard that the youth runs.'

Failure to include $z a$ in non-canonical order focus and question constructions with category one verbs is ungrammatical $(5 \mathrm{a}-\mathrm{b})$, as is the inclusion of $z a$ in canonical order constructions $(5 \mathrm{c}-\mathrm{d})$. 
a. *égbóà ll óll óvbékhán ó ò lá. backyard $\mathrm{PF}$ the youth $\mathrm{SC} \mathrm{H}$ run 'It is in the backyard that the youth runs.'

b. *ébé' ólı óvbékhán ó ò lá? where the youth $\mathrm{SC} \mathrm{H}$ run 'Where does the youth run?'

c. *óli óvbèkhàn ò $\underline{o}$ zà vbí égbóà là. the youth SC $\mathrm{C}$ be.located LOC backyard run 'The youth is running in the backyard.'

d. *óli óvbèkhàn ò $\quad \underline{o}$ là zá vbí égbóà. the youth SC $\mathrm{C}$ run be.located LOC backyard 'The youth is running in the backyard.'

Similar patterns are revealed by clefts and questions related to canonical order constructions formed with the verb gbe 'dance.' $Z a$ does not surface in a canonical order structure with $g b e(6 a)$, but it is obligatory in corresponding clefts and information questions $(6 \mathrm{~b}-\mathrm{c})$. $^{3}$
a. *ólì òkpòsò ò $\underline{\underline{o}}$ zà vbí ókhúnmí ùhài gbè. the woman SC C be.located LOC top well dance 'The woman is dancing on top of the well.'

b. ókhúnmí ùhài li ólı ókpósó ó ò zá gbè. top well $\mathrm{PF}$ the woman $\mathrm{SC} \mathrm{H}$ bellocated dance 'It was on top of the well that the woman danced.'

c. ébé' óll ókpósó $\underline{0} \quad \underline{o}$ zá gbè? where the woman $\mathrm{SC} \mathrm{H}$ be.located dance 'Where does the woman dance?'

${ }^{3}$ The complementary distribution of forms across non-canonical and canonical order constructions is not limited to spatial expressions. For expressions of time, the verb re 'take' occurs in non-canonical information questions (éghé ójé ré hián óli óràn [time Oje take cut the wood] 'When did Oje cut the wood?') but not in canonical declaratives (ójé híán óli órán òdè 'Oje cut the wood yesterday'). 
At this juncture, one might propose that $z a$ arises as a consequence of the focus construction (Goldberg 1995). Za could serve as a formal indicator of focus, much as intonation formally signals Emai polar questions. ${ }^{4}$ If so, $z a$ should be obligatory in focus constructions with other intransitive verbs. As we will see, this is not the case. When NP complements of $v b i$ appear in focus position, intransitive verbs do not uniformly attract $z a$.

Let us now consider the behavior of additional intransitive verbs. Their $v b i$ marked constituents show two distinct word order patterns. For category two and three verbs in canonical order constructions, we find the verb $z a$ with the latter, although only as a verb in series with a locative $v b i$ phrase.

Among category two verbs we find $o$ 'enter' (7a-b). Canonical order constructions with $o$ show that it precedes an obligatory prepositional phrase consisting of $v b i$ and its accompanying NP (e.g. ékóa 'room').
a. óf óvvbèkhàn ó vbí ékóà. the youth move.into LOC room 'The youth entered the room.'
b. *oóli óvbèkhàn ó. the youth move.into 'The youth entered.'

Category three verbs are exemplified by dianre "come out. ${ }^{, 5}$ Canonical order constructions reveal dianre preceded by a vbi-marked phrase (óli é $\underline{k} \underline{a} a$ 'the room' 8a) serving as complement of the verb $z a$ in series. $Z a$ and its $v b i$ phrase

\footnotetext{
${ }^{4}$ Emai polar questions (óli óvbèkhàn ò ó là vbi égbóà? [the youth SC C run LOC backyard] 'Is the youth running in the backyard?') through intonation upturn and raised pitch register, differ from declarative statements (óli óvbèkhàn ò ó là vbí égbóà [the youth SC C run LOC backyard] 'The youth is running in the backyard').

${ }^{5}$ The lexical form dianre appears to have a complex history. Morphologically, it could consist of the verbs $d e$ 'reach,' re 'arrive' and the deictic locative pronoun èàn 'here.' If so, elision of $d e$ 's vowel would be expected but the rise of ean's initial mid-vowel to high front position would have to be accounted for. dianre might also derive from dia 'sit' and re 'arrive' with corresponding adjustment of dia's meaning through grammaticalization or retention of an earlier sense, and addition of nasalization. At this time, there is no comparative or language internal evidence for either hypothesis, and native speakers treat dianre as a single, nonseparable verb.
} 
are optional (8b). The constituent order difference between category one and two is apparent: $z a$, vbi and its complement NP precede rather than follow the verb.
a. óli óvbèkhàn zá
vbí ó
ólı ékóà
diànré.
the youth be.located LOC the room come.out
'The youth came out of the room.'

b. óll óvbèkhàn diànré.
the youth
come.out

'The youth came out.'

The contrasting constituent order patterns for category two and three verbs cannot be reversed. $O$ 'enter' does not accept a preceding $z a$ with its associated vbi phrase (9a). Dianre 'come out' does not permit a following vbi phrase (9b). Moreover, $z a$ cannot appear as the sole verb of a clause (9c); it is dependent on another verb in series. ${ }^{6}$
a. *ólı óvbèkhàn
zá
vbí óli ékóà ó.
the youth
be.located
'The youth entered the room.'
b. *ooli óvbèkhàn diànré vbí ékôà. the youth come.out LOC room
'The youth came out of the room.'
c. *ooll óvbèkhàn zá vbí ooll ékooà. the youth be.located LOC the room 'The youth moved from the room.'

\footnotetext{
${ }^{6}$ Emai dependent verbs fail to occur as the sole verb of a matrix clause, follow immediately an auxiliary or preverb constituent and reflect the tonal pattern of their accompanying matrix verb. In the case of $z a$, it precedes the locative preposition $v b i$ (only verbs precede this preposition), immediately follows auxiliary and preverb (gho 'too/also') constituents (ójé ghó zá

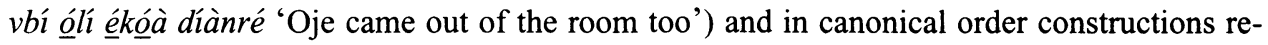
flects the tonal pattern of the matrix verb (zá and initial high tone of diànré). Another dependent verb is $r \underline{e}$, which in series with another verb conveys a range of English meanings ('cause/make,' 'use/take,' 'give/provide,' and 'bring'), but it never occurs as sole predicate of a transitive clause (*òjè ré ikhùnmì 'Oje took medicine').
} 
Category two and category three verbs also behave differently with respect to $z a$ in non-canonical order constructions. Consider NP constituents in focus position that correspond to $v b i$ complements in canonical order structures with $o$ and dianre. When NP complements of $v b i$-marked phrases associated with $o$ appear in focus position, $o$ is the sole verb in the matrix clause (10a-b). $Z a$ in cleft and information questions with $o$ is excluded (10c-d).

(10) a. ól1 ékóáa nà li óli óvbékhán ó -ì. the room this $\mathrm{PF}$ the youth enter $-\mathrm{F}$

'It was this room that the youth entered.'

b. ébé' oól1 óvbékhán ó -ì? where the youth enter-F

'Where did the youth enter?'

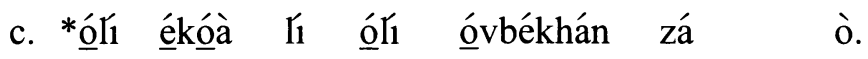
the room $\mathrm{PF}$ the youth be.located enter 'It was this room that the youth entered.'

d. *ébé' ooll óvbékhán zá ò? where the youth be.located enter 'Where did the youth enter?'

Now consider dianre. When the NP complement of its vbi-marked phrase corresponds to a focus position constituent in clefts or information questions, the matrix clause reveals only a single $z a(11 \mathrm{a}-\mathrm{b})$. Cleft and information questions do not allow an additional $z a$ form in the verb phrase (11c-d). They retain only the single $z a$ found in canonical order dianre constructions.

(11) a. ếkọá mè ll ooll óvbékhán zá diànré. room my $\mathrm{PF}$ the youth be.located come.out 'It was from my room that the youth came out.'

b. ébé' ól1 óvbékhán zá diànré? where the youth be.located come.out 'From where did the youth come out?' 
c. *ékóá mè li ólı óvbékhán zá zà diànré. room my PF the youth be.located be.located come.out 'It was from my room that the youth came out.'
d. *ébé' ólı óvbékhán zá zà diànré? where the youth be.located be.located come.out 'From where did the youth come out?'

Other verbs that exhibit behavior similar to $o$ and dianre, respectively, are $s \underline{e}$ 'reach, move as far as' and raale 'move away.' Like its category two counterpart $o, s \underline{e}$ exhibits a postverbal $v b i$ phrase in canonical order structures (12a); it does not allow a preceding constituent consisting of $z a$ followed by a $v b i$ phrase (12b).

a. ólı óvbèkhàn sé vbi édà.
the youth reach LOC river
'The youth reached the river.'

b. *ólı óvbèkhàn zá
the vbíl édà sé.
'The youth reached the river.'

When $s \underline{e}$ 's canonical order construction is compared to its non-canonical order focus construction, one finds $s \underline{e}$ as the only matrix verb (13a-b). As well, NP complements of $v b i$ in canonical order constructions do not pair with focus position constituents in cleft and question constructions that co-occur with both $z a$ and $s \underline{e} . Z a$ is disallowed (13c-d).

a. ólı édá nà li óli óvbékhán sé -ì. the river this $P F$ the youth reach-F 'It was this river that the youth reached.'

b. ébé' ól1 óvbékhán sé -i? where the youth reach-F 'Where did the youth reach?' 


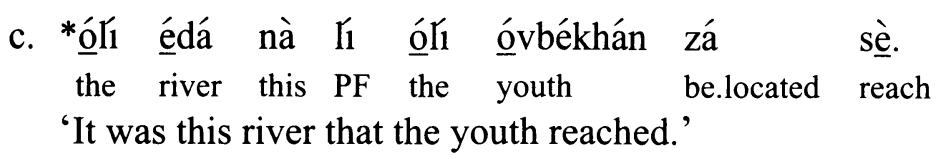
$\begin{array}{clll}\text { d. *ébé' óli óvbékhán zá } & \text { sè? } \\ \text { where the youth } & \text { be.located } & \text { reach }\end{array}$
'From where did the youth reach?'

The verb raale 'move away' exhibits behavior similar to the category three verb dianre. In canonical order constructions, raale is preceded by a constituent consisting of the verb $z a$ and its $v b i$ phrase (14a). It also occurs without $z a$ and its $v b i$ phrase (14b), but it does not permit a following $v b i$ phrase (14c).
a. óli óvbèkhàn zá
vbì iwè ráálè.
the youth
be.located LOC house move.away
'The youth has moved away from the house.'

b. ól1 óvbèkhàn ráálè.

the youth

move.away

'The youth has moved away.'

$\begin{array}{lll}\text { c. *óli óvbèkhàn ráálè } & \text { vbì iwè. } \\ \text { the youth } & \text { move.away } & \text { LOC house }\end{array}$

'The youth has moved away from the house.'

When the NP complement of $v b i$ in canonical order raale constructions corresponds to the focus position constituent in clefts or information questions, only a single $z a$ form occurs; no additional $z a$ attributable to the focus construction appears. A single $z a$, also found in the corresponding canonical order construction, is paired with raale in the verb phrase $(15 \mathrm{a}-\mathrm{b})$.

a. 'iwé mè li óli óvbékhán zá house my PF the youth be.located

(*zà)

rààlé. 'It was from my room that the youth moved away.'

b. ébé' ól1 óvbékhán zá

(*zà)

rààlée

where the youth

be.located be.located

move.away

'From where did the youth move away?' 
Let's take stock of the verb categories in these various constructions by articulating abbreviated lexical entries. For the latter, we specify syntactic subcategorization frame (e.g. < _ PP>), semantic role (e.g. < goal>), optional status of a frame or role with " \{\} ", and possible indexing relations between frame elements. First, consider the verbs $o$, dianre and $z a$.

The verb $o$ takes a subject argument linked to the semantic role theme. It also requires a prepositional phrase linked to the semantic role goal, where goal refers to the point to or toward which an entity moves (Blake 2001). Its lexical entry assumes the shape in Figure 1.

\section{Figure 1.}

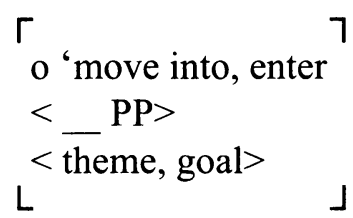

The lexical entry for dianre has a somewhat different syntactic and semantic character. It requires a grammatical subject linked to the role theme, but no other syntactic relation with accompanying semantic role is obligatory. $V b i$ phrases in dianre constructions are complements of the verb $z a$, the entire $z a v b i$ $N P$ constituent being optional. Dianre's lexical entry is shown in Figure 2.

\section{Figure 2.}

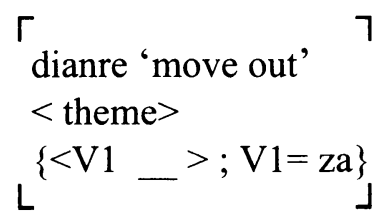

As for the verb $z a$, its lexical entry is distinct. As grammatical subject, $z a$ takes a noun phrase linked to the semantic role theme. As complement, it takes a prepositional $v b i$ phrase linked to the semantic role source, with source referencing the point from which an entity moves (Blake 2001). Moreover, $z a$ and its prepositional phrase must precede verbs like raale and dianre in series. 


\section{Figure 3.}

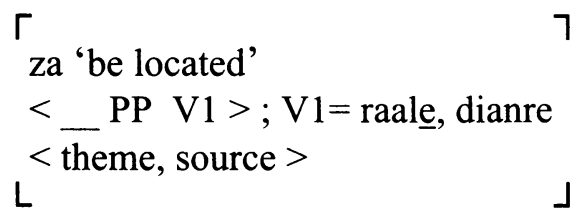

When we turn to category one verbs like $l a$ 'run' and gbe 'dance,' none of the three preceding lexical entry types appears adequate. Since la and gbe do not refer to displacement of an entity, they do not exhibit the semantic role source (like $z a$ with dianre) or goal (like $o$ ). They also do not manifest an obligatory prepositional phrase. Instead, la and gbe show an optional $v b i$ phrase specifying the location at which an activity occurs. Their associated $v b i$ phrase is linked to the semantic role locative, where locative refers to a spatial position (Blake 2001). $L a$ and gbe would thus reflect a lexical entry with subject linked to a theme role and an optional prepositional phrase linked to the semantic role locative, as indicated in Figure 4.

\section{Figure 4.}

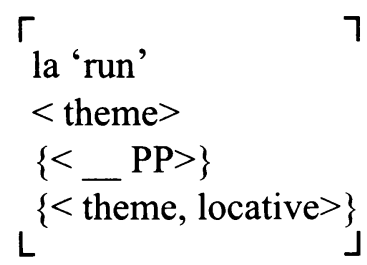

Summarizing to this point, we have concentrated on $v b i$-marked phrases, assessing their syntactic status and the semantic role of their NP complement. For $v b i$ phrases, we identified three semantic role types and three syntactic position types: locative with optional postverbal position $(l a, g b e)$, goal with obligatory postverbal position $(o, s \underline{e})$, and source with an obligatory preverbal position within a dependent verb phrase headed by $z a$ (dianre, raale).

Now we turn to a fourth verb category and its $v b i$-marked phrases. This category is most clearly illustrated by the verb $r i$ 'be located.' In canonical order constructions it has an obligatory postverbal phrase marked by $v b i(16 \mathrm{a}-\mathrm{b})$. 
(16) a. óli óvbèkhàn rí ì vbí isikúù.

the youth be.located LOC school

'The youth is at school.'

b. *óli óvbèkhàn ríi.

the youth be.located

'The youth is. / The youth exists.'

$R i$ permits cleft and information question constructions where the NP of its $v b i$ phrase corresponds to a focus position constituent (17a-b).

a. isikúú mè li ólı óvbékhán rî̀. school my PF the youth be.located 'It is my school that the youth is at.'

b. ébé' ólı óvbékhán rîn?

where the youth bellocated

'Where is the youth?'

Important for our investigation is the fact that focus constructions with ri reject $z a$. Inclusion of $z a$ in the matrix clause with $r i$ is ungrammatical (18a-b).

a. *isikúú mè li óli óvbékhán zá rì. school my PF the youth belocated be.located 'It is my school that the youth is at.'

b. * ébé' óli óvbékhán zá rì? where the youth be.located be.located 'Where is the youth?'

Other verbs in the ri category include muzan 'stand,' me $\underline{\text { hen }}$ 'lie' and dia 'sit.' These verbs with their posture sense are followed by a locative $v b i$ phrase (19a-c), although the latter is not obligatory (20a-c). 
(19) a. oóli ómó múzán-1́ vbí ékóà.

The child stand $-F$ LOC room

'The child stood in the room.'

b. ool loómó méhén-1́ vbí éwàà.

the child lie $-F$ LOC mat

'The child lay on the mat.'

c. ố1 ómó diá vbí ékoóà.

the child sit LOC room

'The child sat in the room.'

(20) a. óll ómó múzán-ì.

the child stand $-F$

'The child stood.'

b. ól1 ómó méhén -ì.

the child lie $-F$

'The child lay.'

c. ốl1 oómó diá.

the child sit

'The child sat.'

NP complements of $v b i$ phrases associated with posture verbs can correspond to focus position constituents. When they do, the accompanying matrix clause contains only the posture verb muzan, méhen or dia (21a-c).

(21) a. ébé' ôol1 ómó múzán -ì? where the child stand $-F$

'Where did the child stand?'

b. ébé' ól ómó méhén -ì?

where the child lie $-F$

'Where did the child lay?' 

c. ébé' ólı ómó diá?
where the child sit
'Where did the child sit?'

Focus constructions with posture verbs do not allow $z a$. Inclusion of $z a$ in these constructions is ungrammatical (22a-c).
a. *ébé' óli ómó zá mùzàn? where the child be.located stand
'Where did the child stand?'
b. *ébé' óli ómó zá where the child be.located lie 'Where did the child lay?' mèhèn? where the child be.located sit 'Where did the child sit?'
c. *ébé' óli ómó zá dià?

Verbs of category four thus exhibit a $v b i$ phrase that occurs in postverbal position. They do not attract $z a$ in constructions where $v b i$ 's NP complement corresponds to a focus position constituent. Category four verbs appear to behave like the verbs of category two, $o$ 'enter' and $s \underline{e}$ 'reach.' The generally similar distributional behavior of their $v b i$ phrases leads one to the initial hypothesis that category four and category two verbs should collapse into a single covert lexical category. Both show a $v b i$ phrase that follows the verb, and both disallow $z a$ in focus constructions. Suppose we then specify the lexical entry for $r i$ as we did for $o$. As subject, ri accepts a noun phrase linked to theme. Its obligatory prepositional phrase would be linked to the semantic role goal.

\section{Figure 5.}

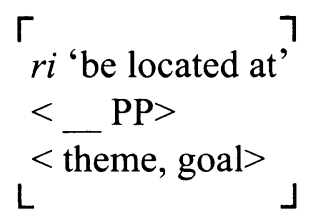


We find Figure 5 inadequate, however, since it links ri's prepositional phrase to the semantic role goal. As our earlier definition indicated, goal assumes a directional schema encompassing spatial positions of onset and termination, i.e. displacement of an entity in space. However, ri, muzan, méhen and dia do not express displacement from one position to another. Category four verbs refer to stative positions in space, not dynamic repositioning of entities. They also reject Emai's continuous aspect (23a-d), consistent with the rejection of progressive aspect crosslinguistically for stative events (Van Valin and LaPolla 1997). Assigning the semantic role goal to the $v b i$ phrase of $r i$ and category four verbs is thus untenable.
$\begin{array}{lllllll}\text { a. *ól1 } & \text { óvbèkhàn } & \underline{o} & \underline{o} & \text { rí̀ } & \text { vbí } & \text { isìúù. } \\ \text { the } & \text { youth } & \text { SC } & \text { C } & \text { be.located } & \text { LOC } & \text { school }\end{array}$
'The youth is being in school.'

b. *ór $\begin{array}{lllllll}\text { ól } & \text { ómò } & \grave{o} & \underline{o} & \text { mùzàn } & \text { vbí } & \text { ékóà. } \\ \text { the } & \text { child } & \text { SC } & \text { C } & \text { stand } & \text { LOC } & \text { room }\end{array}$

'The child is standing in the room.'

c. *oóli ómò̀ ò ó mè̀hèn vbí éwàà. the child SC $\mathrm{C}$ lie LOC mat

'The child is lying on the mat.'
$\begin{array}{lllllll}\text { d. *órl } & \underline{o} \text { ómo } & \underline{o} & \underline{o} & \text { dià } & \text { vbí } & \text { ékóàa } \\ \text { the } & \text { child } & \text { SC } & \text { C } & \text { sit } & \text { LOC } & \text { room }\end{array}$
'The child is sitting in the room.'

One could persist by noting, as several investigators have (Jackendoff 1990, Croft 1991, Frawley 1992 and Talmy 2000), that grammatical resources expressing physical motion also convey real world stative extent. While physical motion goal could then be retained for stative goal and applied to category four verbs, this directional resource hypothesis is still inadequate. Spatial extent (24a) in Emai is expressed by verbs ( $z a$ 'be located' and $s \underline{e}$ 'reach') that otherwise convey physical motion (24b) and retain their semantic roles. However, category four verbs do not convey physical motion, and they are not used to express spatial extent. They denote positional and posture states. 


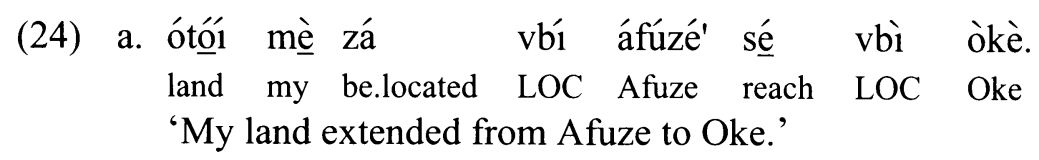

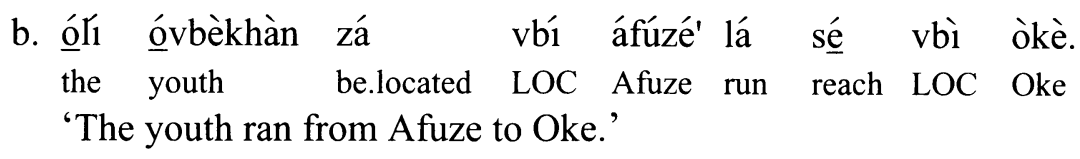

As an alternative hypothesis, recognizing that source is as problematic as goal, we could assign ri's $v b i$-marked NP to the semantic role locative. We might then develop a lexical entry for category four verbs that is similar to the category one verbs $l a$ and $g b e$, as in Figure 6.

\section{Figure 6.}

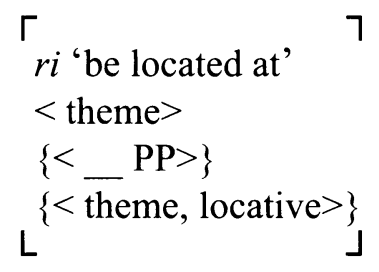

Figure 6 as a lexical entry for $r i$ (and category four in general) is problematic. It posits an optional prepositional phrase linked to the semantic role locative. However, the behavior of $v b i$ phrases for category four (ri, muzan, me $\underline{\text { en }}$ and dia) and category one ( $l a$ and $g b e$ ) verbs are dissimilar. For the former, $v b i$ phrases are obligatory or optional, whereas for the latter they are exclusively optional. And vbi phrases for ri, muzan, me $\underline{\text { hen }}$ and dia do not lead to $z a$ in focus constructions, as they do for $l a$ and gbe. The two verb categories contrast with respect to occurrence of $z a$. The entry in Figure 6 would miss a significant generalization distinguishing the two verb categories. A lexical entry for category four must specify a $v b i$-marked phrase with the semantic role locative and it must preclude the co-occurrence of its $v b i$-marked phrase with $z a$ in focus constructions. The crucial difference between category four ( $r i /$ muzan / menen / dia) and category one $(l a / g b e)$ is the occurrence of $z a$ in focus constructions. A vbi phrase whose NP is assigned the locative role is syntactically obligatory for $r i$, optional for muzan, mehen and dia, and optional for $l a$ and gbe. However this locative role in focus position co-occurs with $z a$ only in the case of $l a$ and gbe. The semantic role locative must have two distinct syntactic realizations. Our interpretation is 
that $z a$ 's complementary distribution accords with the traditional syntactic distinction between adjunct (for $l a$ and gbe) and complement (for ri, muzan, me $\underline{\text { hen }}$ and dia). Adjunct $v b i$ phrases following category one verbs serve an outer locative semantic role, while complement $v b i$ phrases associated with category four verbs serve an inner locative role (Andrews 1985).

This leads us to the entry in Figure 7. It specifies that ri's prepositional phrase is obligatory and that it is linked to the semantic role inner locative.

\section{Figure 7.}

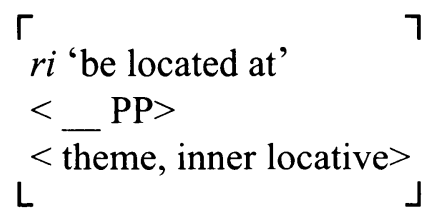

For the posture verbs muzan, méhen and dia, their lexical entry would appear somewhat different. Using muzan to illustrate, its optional vbi phrase complement would be linked to the semantic role inner locative.

\section{Figure 8.}

$\ulcorner$ muzan 'stand'
$<$ theme $>$
$\{<-\mathrm{PP}>\}$
$\{<$ theme, inner locative $>\}$

These behavioral differences regarding intransitive verbs and their $v b i$ phrases lead to the syntactic and semantic conclusions summarized in Table 1. Syntactically, vbi phrases with category four verbs (ri, muzan, me $\underline{\text { hen }}$ and dia) are inner locative complements, while those with category one verbs (la and gbe) are outer locative adjuncts. $\mathrm{Vbi}$ phrases with these verb categories contrast with those associated with verbs from category two $(o, s \underline{e})$ and category three (dianre, raale). With the latter, $v b i$ phrases are complements of $z a$, which serves as an optional verb in series, and they express the semantic role source. As for category two verbs, their $v b i$ phrases are complements that follow the verb and express the semantic role goal. 
Table 1. Properties of $v b i$ Phrases with Intransitive Verb Categories.

\begin{tabular}{|c|c|c|c|}
\hline $\begin{array}{l}\text { Category } 1 \\
\text { la, gbe }\end{array}$ & $\begin{array}{l}\text { Category } 2 \\
o, \text { se }\end{array}$ & $\begin{array}{l}\text { Category } 3 \\
\text { dianre, raale }\end{array}$ & $\begin{array}{l}\text { Category } 4 \\
r i, \text { muzan }\end{array}$ \\
\hline$v b i$ optional & $v b i$ obligatory & $\begin{array}{l}v b i \text { obligatory } \\
\text { in } z a \text { phrase, } z a \\
\text { phrase optional }\end{array}$ & $\begin{array}{l}v b i \text { optional } \\
\text { obligatory }\end{array}$ \\
\hline $\begin{array}{l}v b i \text { after ma- } \\
\text { trix verb }\end{array}$ & $\begin{array}{l}v b i \text { after ma- } \\
\text { trix verb }\end{array}$ & $\begin{array}{l}v b i \text { before ma- } \\
\text { trix verb in } z a \\
\text { phrase }\end{array}$ & $\begin{array}{l}v b i \text { after matrix } \\
\text { verb }\end{array}$ \\
\hline$z a$ in focus & no $z a$ in focus & no $z a$ in focus & no $z a$ in focus \\
\hline adjunct & complement & complement & complement \\
\hline outer locative & goal & source & inner locative \\
\hline
\end{tabular}

\section{Discussion.}

We now probe some details of the preceding analysis. Contrary to our analysis of category one verbs, one could propose for $l a$, gbe and similar verbs, which do not inherently specify a locative role, that $v b i$ phrases in their lexical entry need not be designated as optional. We could assume that outer locative $v b i$ phrases, being determined by pragmatic, contextual factors rather than a verb's inherent lexical properties, could be assigned by a default lexical rule. In that case, a wide array of Emai intransitive verbs should accept a vbi phrase. However, this proposal conflicts with the behavior of two additional verb categories.

Physical property verbs of the type bin 'be dark' and $d a$ 'become high' reject outer locative $v b i$ phrases $(25 \mathrm{~b}$ and $25 \mathrm{~d}){ }^{7}$

${ }^{7}$ Other verbs in this category include rere 'become long,' gba 'become big,' vbee 'become wide,' ime 'become deep,' vbae 'be red,' and fuan 'be white.' 
(25) a. ólı úkpùn bín -ì.

the cloth be.dark-F

'The cloth is dark.'

b. *oóli úkpún bín -1 vbí ékooá mè. the cloth be.dark-F LOC room my 'The cloth is dark in my room.'

c. óli óràn dá -ì. the tree become.high-F

'The tree became high.'

d. *ólı órán dá -1 vb́i 'imé mè.
the tree become.high-F LOC farm my
'The tree became high on my farm.'

To retain the default lexical strategy, one could analyze the $v b i$ phrases in ungrammatical bin and $d a$ constructions (25b and 25d) as instances of extraposition from the subject noun phrase and make the further assumption that such extraposition in Emai is disallowed. English translation of these constructions suggests that the content of $v b i$ phrases serves to modify attributively the subject noun (e.g. ímé mè 'my farm' as modifier of óli órán 'the tree'). And English allows paraphrase expressions where this attributive relation is explicit: The sheet is white on my bed and The sheet on my bed is white.

Following this logic, the $v b i$ phrase in $(25 \mathrm{~b})$ and $(25 \mathrm{~d})$ would be grammatically related to an underlying subject phrase where postverbal extraposition had not occurred. However, as indicated in (26a), the corresponding non-extraposed structure in Emai is also ungrammatical. What is grammatical is a head noun modified by an immediately adjacent relative clause (within which a $v b i$ phrase serves as complement of the category four verb $r i)(26 b)$, not a head noun modified by an extraposed relative clause (26c). Furthermore, notice that there is not a general Emai constraint on extraposition of an entire NP, only a constraint on constituent extraposition from NP, since in (26d) the sentential complement khi clause is the logical subject of the verb hunme 'be fortuitous.' As a consequence, no formal evidence exists supporting an "extraposed from NP" analysis that would account for (25b) and (25d) and that would allow for a default lexical rule to specify constraints on $v b i$ phrase distribution. 
(26) a. *oól úkpún vbí ékooá mè bín -ì the cloth LOC room my be.dark-F 'The cloth in my room is dark.'

b. óli úkpún li ó rì vbí ékóá mè bín -ì. the cloth $\mathrm{R}$ it be.located LOC room my be.dark-F 'The cloth that is in my room is dark.'

c. *ooli úkpún bín -ì $\digamma_{1}$ ó rì vbí ékóá mè ${ }^{8}$ the cloth be.dark-F $\mathrm{R}$ it be.located LOC room my 'The cloth is dark that is in my room.'

d. ò hùnmé khí ólì òkpòsò gbé óli ényè. it be.fortuitous IND the woman kill the snake 'It is fortuitous that the woman killed the snake.'

Restrictions on $v b i$ occurrence are not limited to intransitive property verbs. The verb re 'arrive' also does not allow a vbi phrase, even though its inherent, lexically-specified argument serves as goal of a location change and might therefore be expected to receive $v b i$ marking.

a. ólì èvbòò ré (*vbi) ègùăi.

the villagers arrive LOC court

'The villagers arrived at court.'

b. ól1 ómòhè ré (*vbi) ijóòbù.

the man arrive LOC job

'The man arrived at his job.'

Accounting for the non-occurrence of a $v b i$ phrase by recourse to an extraposed constituent is even less tenable with re since its postverbal noun phrase does not reflect a place property, as was the case with bin 'be black' and $d a$ 'become high'. $R e$ 's postverbal argument specifies end place or goal of location change.

${ }^{8}$ A pause immediately before relator $l i$, leading to a downturn in the intonation contour, could make (26c) acceptable in narrative discourse. But the postverbal relative clause would then not be integrated into the intonation contour of the clause, as it is in English, and instead would have an "afterthought" character. 
Change of location verbs like re and physical property verbs show that $v b i$ phrases and their linked semantic roles must be specified in lexical entries. $V b i$ marked phrases linked to outer locative will need to be specified as optional for verbs like $l a$ and $g b e$ but remain unspecified for verbs like bin and $d a$.

Our analysis also revealed that $v b i$ phrases, regardless of associated semantic role, never occurred as the initial element in focus position or as a stranded element in postverbal position (28a). $V b i$ is prohibited from focus position (28b) and from stranded position relative to either verb in series (28c-d).
a. ókhup
ùhài 1
ól1
ókpósó ó ò zá
gbè.
top well PF the woman SC $\mathrm{H}$ be.located dance
'It was on top of the well that the woman danced.'

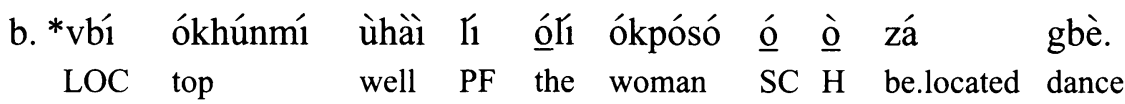
'It was on top of the well that the woman danced.'

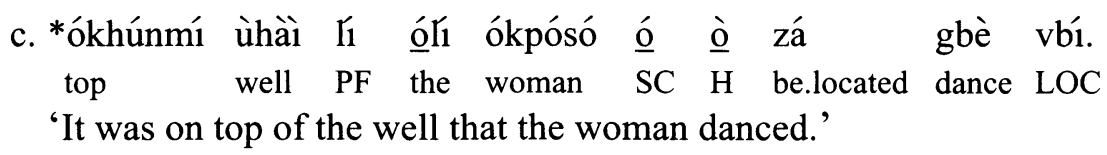
d. *ókhúnmí
ùhài lı
ólı
ókpósó ó ò zá
vbí gbè. top well $P F$ the woman
$\mathrm{SC} \mathrm{H}$ be.located 'It was on top of the well that the woman danced.'

It is possible in narrative discourse for $v b i$ to occur as an emphatic element within a focused constituent, as in (29a-b). ${ }^{9}$ But $v b i$ can never head a constituent in focus position nor can it be stranded. Constraints on preposition stranding are a frequent topic of discussion in the linguistic literature (Haegeman \& Guéron 1999, Huddelston \& Pullum 2002). Exclusion from both focus and stranded positions seems a less frequent topic.

\footnotetext{
${ }^{9}$ Incorporated $v b i$ phrases of this nature seem highly constrained since they only attach to place nouns and only admit as complements a deictic locative pronoun like èvbò. They are most natural in narrative discourse where they appear to serve an emphatic function, i.e. 'the ground right there.'
} 
(29) a. ól1 óvbékhán ýl ólì àbà vbî ótố1 vbì èvbò. the youth pull the pin LOC ground LOC there 'The youth pulled the pin from the ground yonder.'

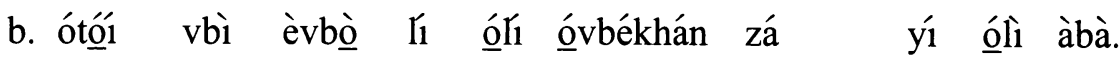
ground LOC yonder PF the youth be.located pull the pin 'It was from the ground there that the youth pulled the pin.'

Relative to the stranded condition, $v b i$ differs from other preposition-like forms in Emai. The latter, which include applicative $l i / n i$ and change of location $\underline{o}$, appear in focus constructions as postverbal stranded forms (30a-c and 31a-c). ${ }^{10}$

(30) a. óli òkpòsò nwú ólı émà ó vbri itébù. the woman take.hold the yam CL LOC table 'The woman put the yam onto the table.'

b. itébú mè li ólı ókpósó nwú óli émà ó. table my PF the woman take.hold the yam $\mathrm{CL}$ 'It was my table that the woman put the yam on.'

c. *ó vbì itébú mè li óli ókpósó nwú óli émà. CL LOC table my PF the woman take.hold the yam 'It was on my table that the woman put the yam.'

(31) a. óli òkpòsò shén émà $\digamma_{1}$ ònwìmè. the woman sell yam APP farmer 'The woman sold yam to the farmer.'

b. ooll ónwímé nà li ooli ókpósó shén émà ní. the farmer this PF the woman sell yam APP 'It was this farmer that the woman sold the yam to.'

${ }^{10}$ The postverbal forms $l i$ and $\underline{o}$ show no affinity to extant verbs in Emai and appear to play a significant function relative to Aktionsart and the expression of event structure. Another postverbal Aktionsart element expressing change is the form $a$. It occurs in canonical order declaratives (óll óvbèkhàn gbé óll ákhè á [the youth break the pot CS] 'The youth broke the pot') and remains in postverbal position in non-canonical order cleft constructions (óli ákhè lí óli óvbékhán gbé à [the pot PF the youth break CS] 'It is the pot that the youth broke'). 
c. * $\digamma_{1}$ ól ${ }_{1}$ ónwimé nà $\digamma_{1}$ ól ókpósó shén émà.
APP the farmer this PF the woman sell yam
'It was to this farmer that the woman sold yam.'

Why does vbi not exhibit similar behavior? One hypothesis is to assume that $v b i$ is the only true preposition in Emai. $L i / n i$ and $\underline{o}$ could be analyzed as postverbal particles central to expression of lexical aspect or Aktionsart (Schaefer $\&$ Egbokhare 2006). If one assumed that a syntactic sanction absolutely constrained prepositions from focus and from a stranded position, prohibitions on $v b i$ distribution would be accounted for.

Still, one is puzzled by the incompatibility of $v b i$ and focus position. Probing further, one could hypothesize that focus position and $v b i$ marking exhibit contrasting information values: focus as new, foregrounded information and $v b i$ as given, backgrounded information. If so, the two would conflict. However, excluding $v b i$ only from focus position and its new information value is insufficient. NP constituents from vbi-marked phrases also occur in topic position, where given, not new, information is registered (Levinson 1983). Nonetheless, $v b i$ itself never occurs in topic position (32a-c).
a. óli óvbèkhàn ó vbí ékóà.
the youth enter LOC room
'The youth entered the room.'

$\begin{array}{llllll}\text { b. ól1 ékóà, ól1 óvbékhán } & \text { ó } & \text { vbì } & \text { ò. } \\ \text { the room the youth } & \text { enter } & \text { LOC } & \text { it }\end{array}$

'As for the room, the youth entered it.'

c. *vbí ól1 ékóà, ól óvbékhán ó -ì.

LOC the room the youth enter $-F$

'As for the room, the youth entered it.'

A broader constraint, perhaps associated with pre-matrix clause (complement) position must exist that excludes $v b i$-headed phrases from focus and topic position. For that matter, $v b i$-marked phrases are also excluded from subject position (33a-b). $V b i$-headed phrases only occur in positions internal to a verb phrase. Our putative syntactic sanction, except under emphatic conditions, must thus preclude $v b i$ from positions outside the verb phrase. 
(33) a. *vbí ólì èkì día (vbì) òjè.
LOC the market sit LOC Oje
'In the market sat Oje.'

b. *vbì is̀ikúù ríi (vbí) éli ívbèkhàn.

LOC school be LOC the youths

'In the school are the youths.'

The verb phrase restriction on $v b i$ raises another facet of its character. Thus far $v b i$ has marked oblique syntactic relations for arguments assigned goal, source or (inner/outer) locative semantic roles. These roles are often referred to as peripheral or as belonging to a thematic tier (Jackendoff 1990). One could naturally assume that $v b i$ is restricted exclusively to arguments expressing peripheral semantic roles. Additional data from Emai shows this generalization to be too restrictive. Under specifiable semantic conditions, $v b i$ also marks lexically specified arguments expressing core or action tier roles, in particular the affected entity in the patient role. More broadly stated, Emai predicates reflect an inverse correlation between $v b i$ marking and the semantic condition affectedness.

Affectedness is widely recognized as a semantic factor influencing the selection of a verb argument for the grammatical relation direct object (Jackendoff 1990, Dowty 1991, Levin 1993, Van Valin \& LaPolla 1997). In the locative alternation pair John loaded hay onto the wagon and John loaded the wagon with hay, wagon as direct object in the latter is more completely affected (i.e. filled) compared to wagon as oblique in the former. In a similar fashion, vbi marking is inversely correlated with argument affectedness. Presence of $v b i$ signals attenuation of a verb's prototypic affectedness condition. For example, the verb $d a$ 'drink' prototypically takes a non-vbi marked argument (óli ényọ 'the wine') as direct object (34a). When this argument is not completely affected by the drinking event (i.e. only some wine is consumed), the erstwhile direct object is marked by $v b i$ (34b). A similar shift in grammatical relations from core direct object to peripheral oblique occurs with the verb $e$ 'eat' $(34 \mathrm{c}-\mathrm{d}) .{ }^{11}$

\footnotetext{
${ }^{11}$ Note also that transitive verbs like $d a$ 'drink' and $e$ 'eat,' do not assume a bare intransitive shape (*óli óvbékhán oo ò dá [the youth SC H drink] 'The youth drinks.').
} 
(34) a. ốl óobbèkhàn dá oól ényò. the youth drink the wine 'The youth has drunk the wine.'

b. ốl óvbèkhàn dá vbí ólı ényó. the youth drink LOC the wine 'The youth drank from the wine.'

c. ól1 óvbèkhàn é ooll émà. the youth eat the yam 'The youth has eaten the yam.'

d. oóli óvbèkhàn é vbí oór émá. the youth eat LOC the yam 'The youth ate from the yam.'

In like fashion, the absence of $v b i$ in constructions where it prototypically occurs signals augmentation of the verb's affectedness condition. Verbs which prototypically mark their inherent argument as oblique with $v b i$ appear in constructions where their lexically specified argument is not marked by $v b i$. This occurs only under conditions deviating from prototypic affectedness. Recall that the category two verb $o$ 'enter' marks its goal argument as oblique with the preposition $v b i$ (7). In constructions expressing abstract emotional conditions, where an experiencer argument is affected by the emotional condition, $o$ does not render its inherent argument as an oblique. Instead, the experiencer argument is realized as a direct object (ohi 35a-b). Vbi marking of the experiencer argument is ungrammatical (35c). Just as with transitive verbs, intransitive verbs show that $v b i$ marking is inversely correlated with affectedness: direct object expression of event argument, i.e. non-vbi marking, correlates with increased affectedness.
a. úéén ísì òjè ò ó rè è̀khối ò òhí. behavior ASS Oje SC C make shame enter Ohi 'The behavior of Oje is making Ohi ashamed.'

b. è̀khọì ó òhí. shame enter Ohi

'Ohi is ashamed.' 

$\begin{array}{llll}\text { c. *èkhöi ó } & \text { vbì òhí. } \\ \text { shame } & \text { enter } & \text { LOC } & \text { Ohi }\end{array}$
'Ohi is ashamed.'

The preposition $v b i$ thus interacts in an inverse fashion with lexical arguments and their construal as affected entities. Under attenuated conditions, $v b i$ 's presence shifts arguments out of the core grammatical relation direct object. Its absence, where otherwise expected, shifts arguments into this core grammatical relation, provided that affectedness relative to prototypic conditions is augmented. Obviously more investigation into possible grammatical alternations employing $v b i$-phrases and lexical prohibitions on $v b i$ marking are required, but these tentative findings serve again to remind us that locative constructions hold more than diachronic interest.

\section{Conclusion.}

This paper has examined the distributional character of Emai prepositional phrases and their NP complements relative to intransitive verbs. $V b i$-marked prepositional phrases exhibit non-uniform distribution with intransitives. In canonical order constructions, a $v b i$ phrase follows a matrix verb or follows the verb $z a$ in series before a matrix verb. In these positions, $v b i$ phrases are optional or obligatory. NP complements of $v b i$ also exhibit asymmetrical behavior. In noncanonical order constructions, focused NP complements with a subclass of verbs lead to the verb $z a$ in series in the matrix clause. We articulate these patterns in minimally specified lexical entries for four verb categories, linking semantic roles to syntactic relations. $V b i$ phrases with the semantic roles source or goal (the former as a constituent of a $z a$ verb phrase in canonical order constructions) reflect complement relations. Remaining locative role phrases, in non-canonical order focus constructions, show complementary distribution of the verb $z a$ in series. Outer locative adjuncts require $z a$, while inner locative complements prohibit $z a$. Finally, we commented on broader syntactic properties of $v b i$, considering its prohibition from syntactic positions outside the matrix verb phrase and its role in the expression of grammatical relations for lexical arguments under contrasting conditions of affectedness. 


\section{REFERENCES}

Andrews, Avery. 1985. "The major functions of the noun phrase". Language Typology and Syntactic Description: Clause Structure, ed. by Timothy Shopen. New York: Cambridge University Press. Pp. 62-154.

Blake, Barry. 2001. Case. Second Edition. New York: Cambridge University Press.

Croft, William. 1991. Syntactic Categories and Grammatical Relations. Chicago: University of Chicago Press.

Dowty, David. 1991. "Thematic proto-roles and argument selection". Language 67: 547-619.

Elugbe, Ben. 1989. Comparative Edoid: Phonology and Lexicon. Port Harcourt: University of Port Harcourt Press.

Frawley, William. 1992. Linguistic Semantics. Hillsdale: Lawrence Erlbaum.

Goldberg, Adele. 1995. Constructions. Chicago: University of Chicago Press.

Haegeman, Liliane \& Jacqueline Guéron. 1999. English Grammar: A Generative Perspective. Oxford: Blackwell Publishers.

Huddleston, Rodney \& Geoffrey K. Pullum. 2002. The Cambridge Grammar of the English Language. New York: Cambridge University Press.

Jackendoff, Ray. 1990. Semantic Structures. Cambridge: The MIT Press.

Levin, Beth. 1993. English Verb Classes and Alternations. Chicago: University of Chicago Press.

Levinson, Stephen C. 1983. Pragmatics. New York: Cambridge University Press.

Lord. Carol. 1993. Historical Change in Serial Verb Constructions. Philadelphia: Benjamins. 
Schaefer, Ronald P.1987. An Initial Orthography and Lexicon for Emai: An Edoid Language of Nigeria. Bloomington: Indiana University Linguistics Club.

Schaefer, Ronald P. \& Francis O. Egbokhare. 1999. Oral Tradition Narratives of the Emai People, Parts I and II. Hamburg: LIT Verlag.

Schaefer, Ronald P. \& Francis O. Egbokhare. 2006. "Emai Forms Expressing State Change". Presentation at $2^{\text {nd }}$ Syntax of the World's Languages Conference. Lancaster University. UK.

Schaefer, Ronald P. \& Francis O. Egbokhare. In press. An Initial Dictionary of Emai: With an English-Emai Index. Köln: Rüdiger Köppe Verlag.

Talmy, Leonard. 2000. Toward a Cognitive Semantics, Volumes 1 and 2. Cambridge: MIT.

Van Valin Jr., Robert D. \& Randy J. LaPolla. 1997. Syntax: Structure, Meaning and Function. New York: Cambridge University Press.

Watters, John R. 2000. "Syntax". African Languages: An Introduction, ed. by Bernd Heine and Derek Nurse. New York: Cambridge University Press. Pp. 194-230.

Williamson, Kay \& Roger Blench. 2000. "Niger-Congo". African Languages: An Introduction, ed. by Bernd Heine and Derek Nurse. New York: Cambridge University Press. Pp. 11-42.

Department of English Language and Literature

Southern Illinois University

Edwardsville, IL 62026-1431

rschaef@siue.edu

Department of Linguistics

University of Ibadan

Ibadan, Nigeria

foegbokhare@yahoo.com [received January 29, 2005, accepted May 21, 2006] 
